\title{
Framing the Frame: Shakespeare and the Cadre
}

\section{by Stuart Sillars}

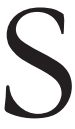

OMETIMES a metaphor can best be realised by taking it literally. From the middle of the eighteenth century to the end of the nineteenth, illustrations to Shakespeare were produced within a variety of physical frames, ranging from the elaborately picturesque to the austerely geometric. The function of frames, and the frames themselves, are often overlooked in the effort to explore the image itself - an unfortunate and ironic, but also inevitable, consequence of the work they ostensibly perform. When they are approached theoretically it is usually to define them as elements of paratext or parergon or, as Nycole Paquin puts it, an 'hors d'oeuvre'1 - in itself an interesting making-real of a term now used wholly metaphorically in the vocabulary of the restaurateur. In The Truth in Painting, Derrida refers to them as something literally marginal: 'une accessoire qu'on est obligé d'accueiller au bord, à bord.' ${ }^{2}$ While his later consideration of frames is as profound and as playful as any of his writing, it concerns their discussions by Kant and other philosophers rather than a direct engagement with their materiality and its effect on the viewer. Elsewhere, material frames have been habitually equated with paratextual items such as title-page, epigraph and chapter heading. But there are functions larger than these, suggesting their force in themselves and in a series of relationships that function in both directions of their physical location - towards the inner text of the image, and outwards upon the beholding circumstance and the beholder within it. My intent here, building on the valuable work of Paquin and Peter Wagner, is to suggest some of these both as a theoretical contention and as a way of revealing their significance as a strand of Shakespeare criticism over the century and a half in which they were prominent. Paquin's rejection of earlier definitions, from Diderot onwards, that sees them merely as 'moulures' or architectural ornaments, is displaced by something far more serious, a form of interpretive dialogue rich in conceptual and theoretical implications. One of the most suggestive is stated in Wagner's remark that the frame 'threatens not the picture but the vision of the one making meaning of/with it.' ${ }^{3}$ The dynamic of this interaction is one of considerable, but too long overlooked, power in the treatment of Shakespeare's plays.

1 'Le cadre' comme lieu de paradoxe au dix-huitième siècle.' Transactions of the Eighth International Congress on the Enlightenment (Oxford: Voltaire Foundation, 1991), vol. 3, 1485-9.

2 La verité en peianture (Paris: Flammarion,1978), 33.

3 Reading Iconotexts: from Swift to the French Revolution (London: Reaktion Books, 1995), p. 76. 


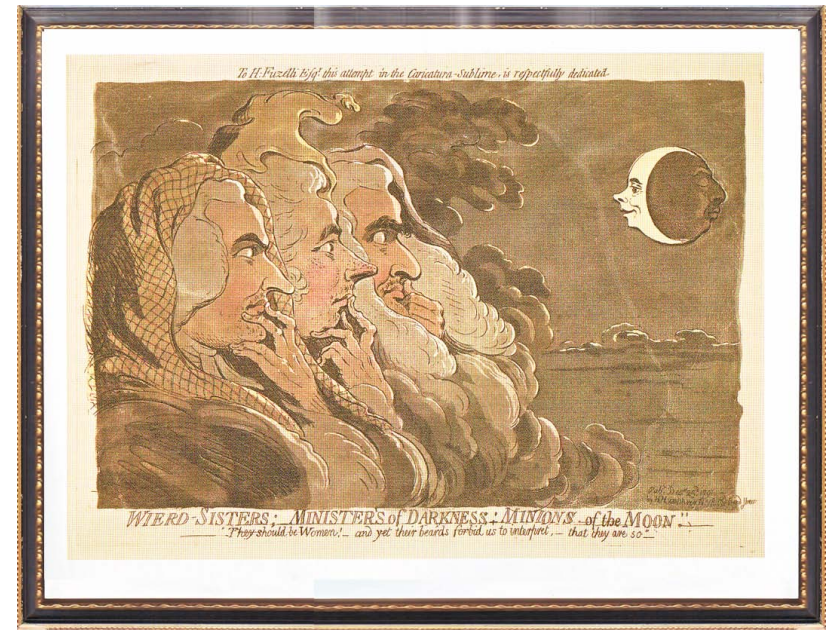

1. Weird Sisters; Ministers of Darkness; Minions of the Moon

Frames to paintings, of course, have several functions that seem to be more direct. One is straightforward protection of the fragile edges of the painted image and its support. Elm or oak panel can splinter and fragment; canvas bent around a timber frame is vulnerable to tears; unsheltered, the pigment on either can easily flake away. There is also the need to define the image as occupying a separate space, in colour, scale and composition, from what surrounds it. Both Blake and Turner used a deep red for the walls on which their paintings were shown in their private galleries - which, of course, were also salerooms - to make this difference more insistent. But Turner also realised that the brilliant, aureate sunrises of his canvases would be defined more completely by avoiding the heavy gilded frames increasingly favoured during his lifetime, demonstrating an early awareness of another result of the frame: it may physiologically, and hence conceptually, pull away from the image at its centre. For Turner this was a matter of colour, but for other artists the frame may act to inhibit or contest rather than enrich the object it surrounds.

The complexity is greater when images are framed long after their original production. It is today the habit to present the aquatints and engravings of James Gillray and Thomas Rowlandson in what are called 'Hogarth frames', thin wooden mouldings with a broken line of gold leaf at their external and internal edges. The effect is simple and elegant. But when it surrounds an eighteenth- century satirical print it may run counter to the visual and ideological effect, which is often a savage political or personal attack, and the image often when first published presented in a 
portfolio or simply pinned to a wall, as depicted as an image-within-image in many of Hogarth's own designs.

Sometimes the pattern of contestation and reinforcement is more complex, more reciprocal. One early example of the consequence of framing in a Shakespeare related text is John Gillray's Weird Sisters; Ministers of Darkness; Minions of the Moon ${ }^{4}$ (Illustration 1) works through a sophisticated pattern of reference. Beneath the image are quoted Macbeth's lines 'They should be women!-and yet their beards forbid us to interpret, - that they are so;' the image itself is a parody of Henry Fuseli's painting The Weird Sisters. ${ }^{5}$ The witches are transformed into likenesses of Lord Dundas, Pitt the younger and Lord Thurlow, respectively Home secretary, prime Minister and Lord Chamberlain during the so-called 'regency Crisis' when the sanity of George II was cause for concern. The king himself, and Queen Charlotte, are shown in profile as the two sides of the moon. Fully to grasp the satiric nature of the print a considerable range of knowledge is needed - of Shakespeare's play, Fuseli's painting, and not only the political situation but the physical appearance of its main characters. Its satiric thrust is strong, but its contemporaries regarded it as an ephemeral commentary, but this identity changes when the print is encased in a Hogarth frame. The elegant bordering, and the compound new text to which it contributes, suggest that the dialogue between sophisticated artistic concerns and the quotidian squalor of political intrigue in which later viewers have cast eighteenth-century constitutional activity is, at the very least, a reasonable hypothesis through which to approach the actuality. And so the physical frame and the conceptual apparatus of engaging with the image, and its own engagement both with Shakespeare and contemporary activity, come together as mutual mirrors, each a metaphor to enrich the other. It is through such relationships, as well as through the physical funnel of the frame, that the actual and conceptual definitions of Shakespeare's plays from an earlier age are inevitably perceived by subsequent readers. I shall return to the material and ideological implications of framing as a later act of redefinition, but now turn to my main concern: the nature and effect of the frames designed to surround prints that present moments of action from the plays in English editions of the eighteenth and nineteenth centuries.

In his important and influential study of eroticism in French prints of the eighteenth century, ${ }^{6}$ Philip Stewart makes no mention of the elaborate cadres by which the images were often surrounded, missing an opportunity to explore their contribution to the teasing play with the desire of the spectator through which they

4 Aquatint, $25.5 \times 35.5 \mathrm{~cm}$ (10 x 14"), published 23 December 1791.

5 1783; oil on canvas, 65 x $91.5 \mathrm{~cm}$ (25 1/2 x 36"), Kunsthaus Zurich. Engraved by John Raphael Smith in 1785.

6 Engraven Desire: Eros, Image and Text in the French Eighteenth Century (Durham NC and London: Duke University Press, 1992). 
Framing the Frame: Shakespeare and the Cadre

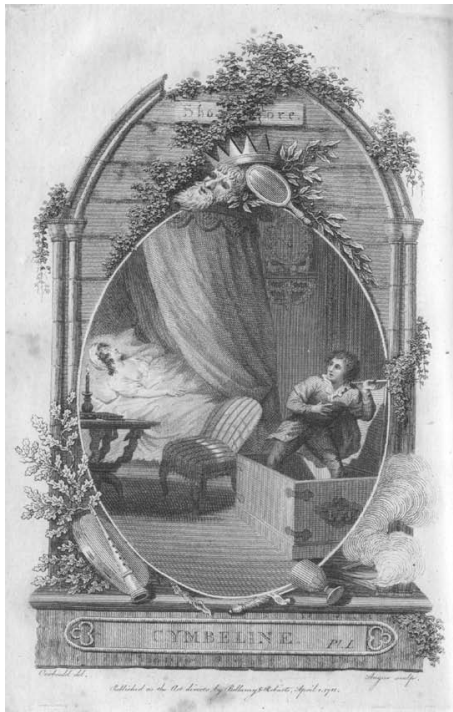

CYMBELINE.

Such, and fuch piefures:- There the window:- Suc The adornment of her bed ; - The arras, figures? Why, fuch, and fuch :-And the contents o
Al, but fome natural notes about her body (Abcre ten thoufand meaner moveables O fleep, thou ape of death, lie dull upon her! And be her fenfe but as a monument, Thus in a chapel lying! - Come off, come off ; - As flippery, as the Gordian knot was hard! 'Tis mine ; and this will witnefs outwardly, As ftrongly as the confcience does within, To the madding of her lord. On her left breaft A mole cinque-fpotted, like the crimfon drops The bottom of a cowflip: Here's a voucher, Will force him think I have pick'd the lock, and ta'en The treafure of her honour. No more,-To what end Why fhould I write this down, that's riveted, Screw'd to my memory? She hath been reading late The tale of Fersus; here the leaf's turn'd down Where Pbilomel gave up_- 1 have enough: To the trunk again, and fhut the fpring of it.
Swift, fwift, you dragons of the night! that dawning May bare the raven's eyc: $I$ lodge in fear: Though this a heavenly angel, hell is here.

Though this a heavenly angel, hell is here. [Clock frikes.
[Co One, two, three:-Time, time! [Goes into the Trunk: the Scene clefes.

$\frac{\text { SCENE III. }}{\text { Auther Room in the Palace. Enter Crotes, and two }}$
Lords.

I Lord. Your lordhip is the moft patient man in lofs, the moit coldeft that ever turn'd up ace.

I Lord. But not every man patient, after the noble temper of your lordlihip: You are moit hot, and furious, when you win.

D 2 Clot.

\section{Cymbeline}

70

TrOILUS AND CRESBIDA, AEZ III

fetches her breath as short as a new-ta'en sparrow. Exit PANDARUS.

Troi. Even such a passion doth embrace my bosom:

My heart beats thicker than a fcrerous pulse; And all my powers do their bestowing lose,

Like vassalage at unawares encount'ring

200

The eye of majesty.

Enter Pandarus, and Cressida.

Pan. Come, come, what need you blush ? shame's a baby.-Here she is now : swear the oaths now to her, that you have sworn to me.-What, are you her, that you have sworn to me.-What, are you gone again ? you must be watch'd ere you be made tame, must you : Come your ways, come your ways; an you draw backward, we'll put you i' the files. Why do you not speak to her --Come, draw this curWhy do you set's see your picture. Alas the day, how tain, and let's see your picture. Alas the day, how loth you are to offend day-light! an 'twere dark,
sou'd close sooner. So, so ; rub on, and kiss the yistress. How now, a kiss in fec-farm! build there, carpenter; the air is swect. Nay, you shall fight you hearts ont, ere I part you. The faulcon as the tercel, hearts ont, ere 1 part yon

215 for all the ducks i' the river; go to, go to.
Troi. You have bereft me of all words, lady.

pan. Words pay no debts, give her deeds : but she'll bereave you of the deeds too, if she call your attivity in question. What, billing again? here sIn witness wherenf the parties interchangcably - Come in, come in; I'll go get a fire. [Exit PANDaRUs.

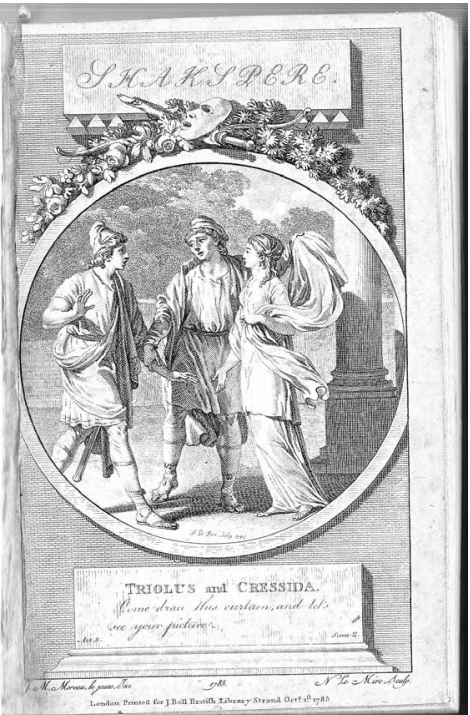


defer and augment the appreciation of the images they surround. The reference is more than a passing statement of regret, since it suggests both the origin of the framing practice in English Shakespeare engravings and an analogy for their function in relation to the engravings they enfold: it is one in which the desire of the viewer is aroused and enriched, and yet also playfully deferred. We can see this at its most direct, as well as its aesthetically most playful, in the illustration to Cymbeline (Illustration 2) that appeared in the Bellamy and Roberts edition that appeared in serial parts between 1788 and $1791 .^{7}$ The image at the centre shows Iachimo in Imogen's chamber. While not approaching the erotic particularity of the prints that Stewart discusses, it nonetheless presents one of the most sexually charged passages of any of the plays, transposing it from the recorded action of the play text to the witnessed event depicted in an engraving. Like all the frames in the edition, it enacts a version of the Picturesque at once indicative and parodic. The columns of the frame's perimeter move towards a Gothic arch, but the arch is broken at the top. The ancient stone is randomly overgrown, the fronds obscuring the trompe l'oeil incision of 'Shakespeare' within the arch and in places overlapping into the picture space itself. The inner boundary is topped by motifs emblematic of classical theatre - the mask of tragedy, the crown of kingship, the mirror of mimesis. At foot a drum and tabor, and a chalice and sword, suggest other arenas of acting and action. And beneath all of this a ledge is projected towards the viewer, on the front panel of which is incised the play's title.

These elements are present in all of the plays. The whole structure they constitute is playful in its references to Picturesque ruin - perhaps the Picturesque is always already playful in its self-reflexive construction of decay - but in this it reveals much about an approach to Shakespeare. The plays, it implies, are ancient, but they are still fresh: they are serious and engagingly comic, classical in status and insistently contemporary. But this has special resonance within this particular image. We see through, not past it: it is not a border, not an architectural moulure or geometrical string course, and our passage is as much delayed as facilitated by its presence, a deferral equivalent to the restraint of frames in contemporary French engraving. Significant in any framing, here it has the double significance of offering an analogy to the events depicted: as Iachimo emerges from the trunk to view the partially clad and wholly vulnerable Imogen, so we emerge through the frame to engage in a scopophilic vision of the events. This movement introduces another, in the image itself. As Iachimo's eyes draw us across, we are made conspirators in his act of vision: we come to occupy the vacant seat that is placed in the centre of the composition. Even without the frame, we would have been embroiled in this act: but its presence both introduces and intensifies this involvement through delay.

7 The Plays of William Shakespeare, complete in eight volumes (London: Bellamy and Robarts, 1788-91). 
At the same time, the frame holds us at bay from the action. The mirror at the top of the inner border, echoing the shape of the central recess, reminds that we are watching a construction, the mirror held up to nature of which Hamlet speaks. The frame as a totality is also a physical boundary, its masonry mimicking a memorial tablet, so that even while it stresses contemporaneity in its Picturesqueness it reminds us of the passage of time. And for us, as much later viewers, the style is no longer immediate. It is at this stage that the concept of reframing comes into play - at this stage, and also from the very start of its discussion, since the text that I am writing and you are reading is a reframing of the image within early twenty-first century critical terms, with all the complexities, astigmatisms and idiosyncrasies that they offer, enriched and imperilled by poststructuralist anxieties and personal identities of writer and reader.

Most extreme in this image, the framing convention is forceful elsewhere. The second of John Bell's editions, the so-called 'Scholarly' version of 1788, ${ }^{8}$ uses frames that are much more restrained, but the play is still clear, nowhere more than in the Troilus and Cressida print (Illustration 3). Again, play is made of desire and deferral, immediacy and delay, the actual and the acted, and the image designed by Moreau le Jeune, the prolific and influential French designer-engraver, continues the erotic function of the frame in controlling and enticing. The design takes as its ground a simple brick wall, with trompe l'oeil tablets at head and foot; below, the play's title and a crucial line of text, above the celebratory word 'Shakspere' in the antiquarian spelling of the day. The central recess through which the image is seen is perfectly circular, a spy hole through which we observe Pandarus unveiling Cressida to Troilus. As the frame both invites and withholds, so does Pandarus, his hand firmly gripping the wrist of Troilus to control his access. The image plays with its own visual identity in many ways. As a perfect circle in which the characters are shown in profile it at once echoes and undermines the status of a classical medallion, a status of which the characters are manifestly unworthy. The column to the right makes allusion to the use of the figure in countless society portraits Reynolds, Gainsborough and their lesser imitators all used it as a prop to establish worth and breeding in painting the wives of recently ennobled mercantilists, and the ironies are revealed in its presence in the Troilus image. And the line that is caption makes a further allusion: 'Come draw the curtain and let's see your picture' (III.2.45-6). The reference is to the custom, common in the eighteenth century as in Shakespeare's time, of exhibiting rare paintings behind velvet curtains that were drawn aside only to reveal the image to the privileged. Its use here is another declaration of ownership and control by Pandarus, but also a hint at Cressida's identity as a painting, a falsehood. At the same time, it enacts another falsehood; this is an

8 Bell's Edition: Dramatic writings of Will Shakespeare, With the Notes of all the various Commentators; printed complete from the best editions of Sam. Johnson and Geo. Steevens. 20 vols. (London: J. Bell, 1785-88). 


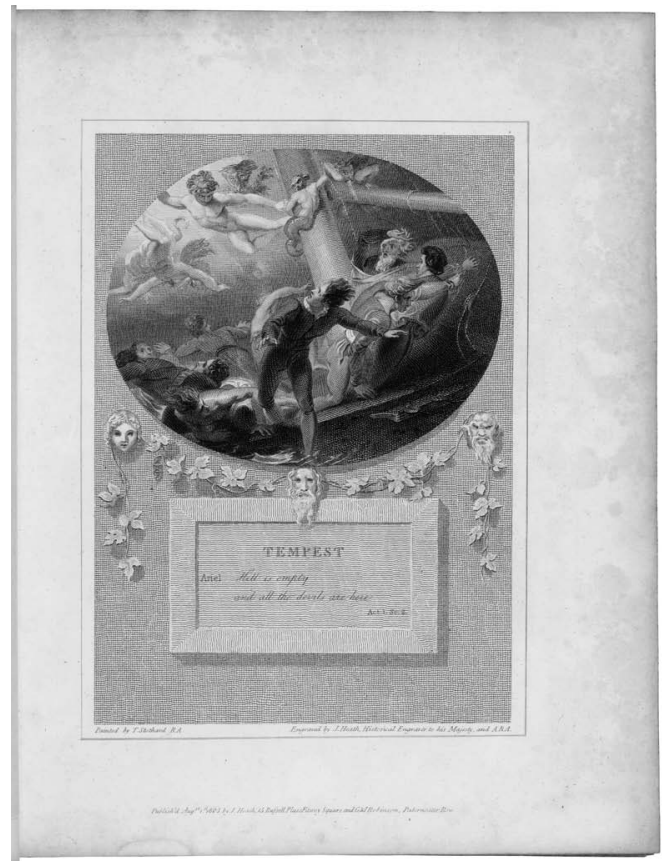

4. The Tempest

engraving, not a painting, and it is available for all to see. Invitation and deferral again - the framing function goes through and beyond the frame, but without the presence of the frame it would be far less subtly doubled and controlled.

In succeeding editions of the plays the frame adopts a series of other forms, with corresponding shifts of function. The Heath Shakespeare, ${ }^{9}$ produced in a much larger, folio format, enlarges the frame so that it occupies two thirds of the print area, the image constrained within it and sometimes, as in Stothard's treatment of the opening of The Tempest (Illustration 4), using forceful diagonals to make characters plunge straight at the viewer. Here the usual function is reversed: instead of the frame inviting and delaying, the action thrusts outward: the frame, in short, collaborates in a construction of the play's movement that leads to the multiple returns of its conclusion. Prospero returns to Milan, but the actor also returns to actuality. 'If from your sins you'd pardon'd be/ let your indulgence set me free' is foreshadowed by the outward thrust and pulse of the central figures, and the frame is again playfully drawn into the visual configuration of the play.

Frames do not always share the planar independence of these designs. Those

9 Dramatic Works...from the corrected text of Johnson and Steevens. Embellished with Plates. 6 Vols (London: J. Stockdale, 1807). 


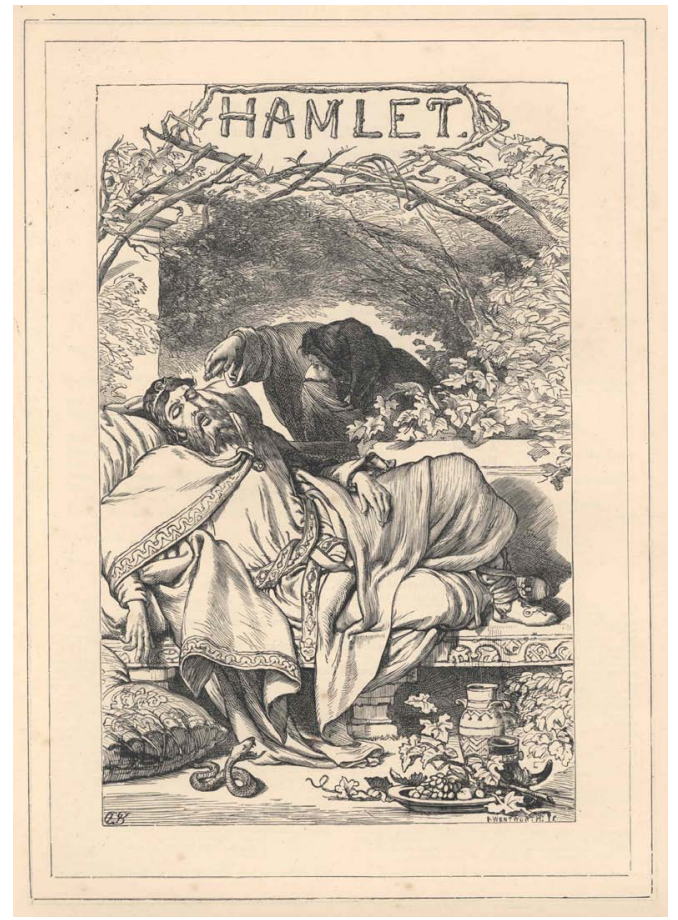

\section{Hamlet}

of the high Victorian age interweave with the images they offset, to form not so much a restraint but a coruscation: they draw us in and hold us back by turns, through a rippling between worlds of dramatic event and visual introduction. H. C. Selous's title pages for the Cassell edition ${ }^{10}$ work within a double frame. The first is a simple lined border of the kind applied to topographical watercolours from the early eighteenth century, a frame in its conventionality almost invisible to the practised reader. But often it leads to another second frame. The design for Hamlet (Illustration 5) shows Claudius poisoning the king beneath an open pergola, the rustic branches of which are echoed in the forming of the word hamlet. The caption thus grows out of the frame: the pseudo-classical ornamentation of the garden gives way to a recognisably contemporary feature of Victorian gardening - Tennyson's

10 Cassell's Illustrated Shakespeare. The Plays of Shakespeare. Edited and Annotated by Charles and Mary Cowden Clarke, authors of "Shakespeare Characters", "Complete Concordance to Shakespeare", "Girlhood of Shakespeare's Heroines," \&c. 3 vols (London: Cassell, Petter, and Galpin, 1864). 


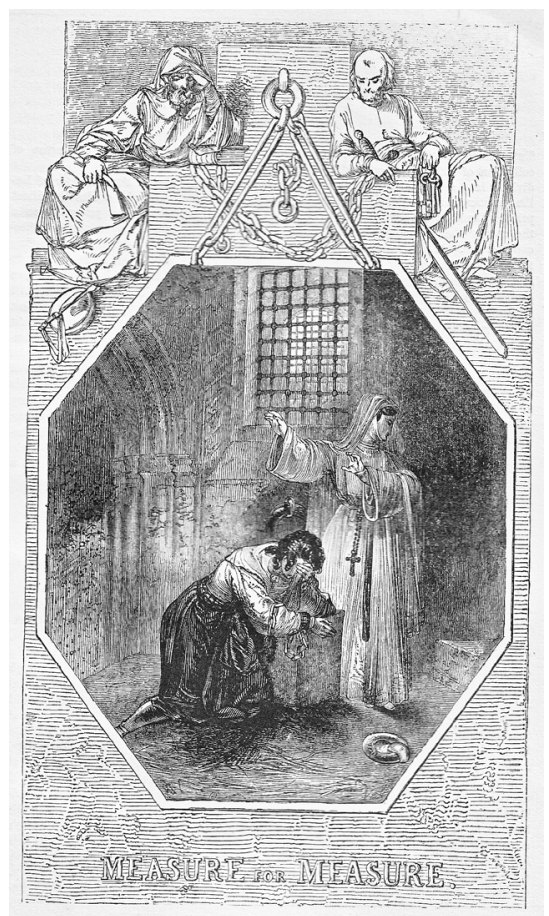

\section{Measure for Measure}

speaker would have recognised it while waiting unavailingly for Maud. Frame and event, imagined past and experienced present, coalesce: the title script joins with the serpent at the foot of the image to remind the reader that we are complicit in this fall and all others.

More complex in intersection are those for Charles Knight's Pictorial Shakspere of the 1830s. ${ }^{11}$ Measure for Measure (Illustration 6) develops the convention of the memorial niche, but adds to it through a configuration that in effect provides multiple frames. The scene is not shown as through the wall of an ancient building, but as an image hung upon it, with vague, troubling allusions to a votive scene. The figures above are not independent, but look down with evident disapproval, chan-

11 The Pictorial Edition of the Works of Shakspere. Edited by Charles Knight. (London: Charles Knight and Co, 56 monthly parts, 1838-43). Issued as 7 volumes, with an additional supplementary volume containing the life of Shakespeare. Subsequent versions included 'The National Edition.' 3 vols. (London: Routledge, 1858). 
nelling the eye of the reader to the image and focussing her or his response in a clear ethical direction. The distinction between action within and reflection without the play is maintained: the left-hand figure is clearly Escalus as the monk, that on the right St Peter, emblematically identified through his heavy keys. The geometric rigour of the octagonal opening through which the scene itself is entered is reflected in the close grid of the prison window and the elegant mullions of another window, presumably of a neighbouring building, seen beyond it. Darkness on either side of the pair offers another frame. All suggests enclosure and constraint, but not so much through a careful delay caused by the frame but by the frame itself becoming a major protagonist in the image's structure, aided by the action being frozen as Isabella turns away from Claudio. It is a moment of moral judgment that is presented here, a visual parallel to the parables of Carlyle and Ruskin, through the architectural forms canonised in the same decade by Pugin.

All of these framings are, of course, surrounded by others. The very absence of frame in the first images to Shakespeare, those of Nicholas Rowe, ${ }^{12}$ itself constitutes a framing. Presented opposite simple, declarative title-pages - they are among the very earliest to make a clear distinction between frontispiece and title page they show themselves part of a new economy of Shakespeare publishing, the pages left open in stationers' windows to draw in customers, a frame that marks the entry of the dramatist into a commercial arena far larger than the more restricted codes and formal procession of the Folio's opening pages, itself a regal procession of epistles dedicatory rather than an act of invitation and deferral.

These images and their framing structures, important as components of the reading experience at a level probably not consciously absorbed by their original viewers, and rarely if ever the basis of comment by subsequent commentators, offer themselves as important metaphorical and conceptual guides to the larger complexities of reading and reinvention in which we are all engaged. The very fact of their original silent assimilation reveals the innate presence of ideological and interpretive values within cultural objects: they are there no less directly, and no more easily seen around, because of their invisibility within the larger ideological conspectus. The silence of subsequent observers, like the frames themselves, presents both an invitation and a barrier. It reveals the introspection from which we all, as critics, suffer; we are all prisoners of our own generation, and the valuable and right movement towards new invention too easily blinds us to the values and opportunities of those already there. Ideological frames can splinter and fragment, impeding the view of the object they surround as easily, and sometimes as visibly, as their material counterparts. But they may also suggest the chance of renewal

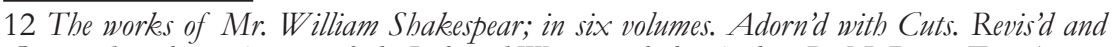
Corrected, with an Account of the Life and Writings of the Author. By N. Rowe, Esq. (London: Jacob Tonson, 1709). 
and reinvention through the consideration of concepts and constructions silenced or made invisible through the accretions of disuse, or the distortions of overlong familiarity. In these categories, the frames stand respectively for, say, the work of Richard Moulton or A. C. Bradley. ${ }^{13}$ The intersections and exchanges, as well as the dynamic of invitation and refusal, that such acts of conceptual enclosure offer, remind us of the values as well as the processes of framing and reframing with which this collection is concerned.

Yet this is too simple, and too straightforward an ending: while the physical frames present an immediate analogy, there are insistent differences that force the two concepts away from such a convenient parallel. The frames constructed in the eighteenth century illustrations, for all the ideological determinants they offer, for all their re-visionings from an historical horizon remote from that of the plays, are engagements of an aesthetic directness quite different from the stance of academic - or, in European terms, scientific - rigour adopted, however imperfectly, by later generations of critics. Implicit within the academic stance of the early twentyfirst century, too, is a degree of anxiety absent from both these earlier aesthetic casings. The anxiety shows itself in two drives: one, to anchor every concept in a contemporary theoretical sediment, a validation through the signature of one of the great figures of theoretical discourse; the other, to avoid any and all allusion to pastness in a movement so acutely self-conscious as to assigning itself the title of presentism. These viral identities of anxiety themselves form a frame, but one of a very different kind: the pastness of theory, the pastness of history, the postness of postmodernism are all asserted in different, paradoxical forms, and combine to form a new frame. From such a standpoint, the frame has become a border: from the edges, the search for a new way of seeing becomes simultaneously insistent and disabled.

Stuart Sillars

University of Bergen

13 Respectively in Shakespeare as a Dramatic Artist (Oxford: Clarendon Press, 1885) and Shakespearean Tragedy: Lectures on Hamlet, Othello, King Lear, Macbeth (London: Macmillan, 1904). 